\title{
PRE-SERVICE TEACHERS' PERCEIVED CONCERNS AND BENEFITS DURING PRACTICUM
}

\begin{abstract}
The study focused on pre-service teachers' benefits from teaching practice, and the problems they experienced during practicum. Using document analysis method, the data were obtained from their portfolios which included self-evaluation forms, weekly journal entries, and summary reports of their teaching experience. The results indicate that a) teaching practice is a turning point for pre-service teachers, b) it was the practicum opportunity rather than the coordinating teachers' support that mattered, c) selection of the coordinating teachers was not done effectively, $d$ ) more experienced coordinating teachers followed conventional methods, e) the more practical the university courses the less problems the pre-service teachers experienced.
\end{abstract}

Keywords: pre-service teachers; practicum; practicum concerns; practicum benefits; teacher education.

\section{Introduction}

Teaching practice indicates a turning point for most pre-service teachers. Researchers agree that it is the most significant period during their teacher education program (Clarke \& Collins, 2007; Clement, 1999; Darling-Hammond, 2006a; Farrell, 2008; McDonald, 1993; Mitchell \& Schwager, 1993; Ramsey, 2000; Richards \& Farrell, 2011; Tsui, 2003; Zeichner, 1990). As Lehsem and Bar-Hama (2008, p. 257) indicate, "Quite often trainees claim that they benefit more from spending time in the field watching others teach than from attending sessions at the university or colleges." It is a totally new environment where pre-service teachers have opportunities to demonstrate their teaching skills in a real-life situation, to conduct trial and error practices, and to test their hypotheses regarding their teaching principles established during their university courses. Teaching practice thus has the following benefits: It provides an environment a) to improve teaching skills, b) to put theory into practice, c) to develop a teacher identity (Gezegin-Bal, Balıkçı \& Gümusok, 
2019; Kırmızı \& Tosuncuoglu, 2019); d) to "confirm their career choice" (Elligate, 2007, p. 66), and e) to develop reflective and independent thinking (Elligate, 2007).

Research suggests that considering and responding to pre-service teachers' concerns substantially improves teaching practice applications (Briggs \& Richardson, 1992; Chan \& Leung, 1998; Harwell \& Moore, 2010). As Goh and Matthews (2011, p. 93) state, "There was a better chance of eliminating problems encountered by student teachers if more was known about the difficulties they faced and the source of their concerns." Therefore, it is imperative to draw on pre-service teachers' experience during the practicum process as such information will help us provide better practicum opportunities for them.

\section{Pre-service teachers' perceived concerns and benefits}

Research on pre-service teachers' teaching practice focuses on both their concerns and potential benefits from their experience. This section will review the literature in terms of their concerns and likely benefits in practicum programs.

Pre-service teachers investigated in Liaw's (2012) study indicated classroom management as one of primary concerns during practicum. Valdez, Young, and Hicks (2000) also found out that classroom management included 30\% of the problems while problems concerned with teaching were the most serious with a percentage of 48 among pre-service teachers. Individual differences rated 12\%. A similar research has been conducted by Swennen, Jörg, and Korthagen (2004) about student teachers' concerns which found the following categories: concern about teaching, concern about students' needs, and individual and general concerns.

Baum and Schwarz's (2004) study indicates that communication skills, neglected in teacher education programs, is the biggest concern among pre-service teachers. Kyriacou and Stephens 1999), on the other hand, emphasized the following concerns raised by pre-service teachers: a) anxiety over students' perceptions of themselves as real teachers or not, b) classroom management, c) planning and instruction, d) anxiety over their performance.

As for their likely benefits, the above authors listed the following: taking responsibility, developing confidence and creating an appropriate management environment. Similarly, Peters (2008) investigated pre-service teachers' learning outcomes from teaching practice and found out that most learning occurs on classroom management (100\%) followed by catering for students' diverse needs (90\%). Effective teaching, planning and organization, and relationships rated $60 \%$, $47 \%$, and $43 \%$ respectively.

Following a review of the benefits and concerns on the part of pre-service teachers, the next section will highlight some concerns regarding the effectiveness of teacher education programs in general and their connection to practicum programs in specific. 


\section{Concerns about teacher education programs}

The literature review indicates that teacher education programs should be reformulated taking the following problems into consideration.

1. The courses in teacher education programs are usually unrelated, which hinders their contribution to the practical component of the curriculum (Zeichner \& Gore, 1990) or conducted using inappropriate teaching methods (Ingvarson, 2007, cited in Uusimaki, 2009).

2. Theory and practice are not integrated appropriately in teacher education courses (Darling-Hammond, 2006a; Masadeh, 2017; Rorrison, 2008, 2011; Stuart \& Thurlow, 2000; Watson, 2005); and theory is overemphasized in the programs (Liston, Whitcomb \& Borko, 2006; Ramsey, 2000; Watson, 2005). Pre-service teachers expressed their concerns about inadequate training in practical issues such as classroom management and discipline problems (Hogan, Rabinowitz \& Craven, 2003; Can \& Basturk, 2018; Ozdas, 2018; Ramirez, 2019). They also expressed their inability to transfer theoretical knowledge obtained from university courses to the classroom situations during practicum (Tas \& Karabay, 2016).

3. The disconnection between teacher education programs and the school community is also a major problem in teacher education (Bullough, Draper, Smith \& Burrell, 2004; Cavanagh et al., 2019; Darling-Hammond, 2006a; Naylor, Campbell-Evans \& Maloney, 2015; Ramsey, 2000; Vick, 2006; Zeichner, 2006; 2010). Research shows that ensuring such a connection provides more effective teacher preparation for complex teaching environments (Darling-Hammond, 2006b; Tatto, 1996; Zeichner \& Conklin, 2005). Darling-Hammond (2006a, p. 307) summarizes how such a link could be made possible: "Extensive, well-supervised clinical experience linked to course work using pedagogies that link theory and practice." Her suggestion is that pre-service teachers spend considerable time in practice throughout the whole program rather than spending time in practice for a specified period.

4. Due to high demand for school placements of pre-service teachers, coordinating teachers cannot provide adequate support to them as they are already busy with the heavy work load of teaching and other duties (Ingvarson, 2005, as cited in Elligate, 2007).

5. University supervisors are not always effective as they may not be qualified enough to supervise effectively (i.e. assigning graduate students or academic staff from other disciplines for supervision) (Zeichner, 2010). Supervisors' availability for consultation is another contribution to the effectiveness of practicum sessions (Roland, 2010).

6. Some pre-service teachers received most of the guidance from university supervisors (Farrell, 2008; Pennington \& Urmston, 1998) rather than 
from coordinating teachers. A meta-analysis of 25 studies showed that coordinating teachers are not always as directive and helpful as expected nor can they provide intended support and guidance all the time (Hansford, Ehrich, \& Tennent, 2004). The following section is to detail such problems connected to coordinating teachers' responsibility.

Coordinating teachers:

- could be too controlling (Brandt, 2006; Pennington \& Urmston, 1998) and interfering. One teaching practice student indicated how badly they were affected when coordinating teachers interfered too much during their teaching time as expressed in the following: "I could hear my voice and also the teacher's voice. This made me uneasy and I couldn't concentrate." (Taskin, 2006, p. 393) As Rorrison (2008) and Uusikami (2009) state, such a practice imposed by coordinating teachers may damage pre-service teachers in their endeavour to develop their professional identities.

- $\quad$ do not always provide adequate feedback and support (Eby et al., 200o; Elligate, 2007; Hansford, Ehrich, \& Tennent, 2004; Peters, 2008; Rorrison, 2008; Schutz \& Zembylas, 2009; Taskın, 2006; Zeichner, 1990).

- do not always trust pre-service teachers; thus, do not give them due responsibility. Some coordinating teachers assign practice teachers repeat classes to teach (Taskin, 2006).

- usually follow a teacher-centred approach and as a result, pre-service teacher feel pressure to act in accordance with coordinating teachers' academic demands (Farrell, 2008). As Zeichner (2010) emphasizes, some coordinating teachers are not familiar with the course content of the campus courses. This is especially true if they have not refreshed their knowledge on the current developments in teaching methodology. This, as a result, can cause clashes in the selection of teaching techniques, activities and materials.

- $\quad$ are not selected effectively (Eby et al., 2000; Elligate, 2007; Zeichner, 1996, 2010). The selection is made either by the judgment of the school principal or the teacher's volunteering (Guyton \& McIntyre, 1990). It is also interesting to note that trainees wish to be assigned a second coordinating teacher in case of communication breakdown with the first one (Brandt, 2006).

- could sometimes see the teaching practice time as a break from teaching and leave pre-service teachers on their own (Farrell, 2008).

On the other hand, coordinating teachers rightfully complain that they are not well informed of their roles and responsibilities during the practicum. They try to compensate through consultations with their peers and reflections on their background as a coordinating teacher (Richards \& Farrell, 2012). Coordinating teachers also emphasize "the need for university supervisors to ensure timely communication with them" during practicum (Roland 2010, p. 43). 


\section{Teacher education programs and the practicum}

The above literature review shows the following connections be made between teacher education and practicum programs:

- the courses in teacher education programs should provide a good transition to the practicum sessions emphasizing practical components;

- the university should have effective communication channels with the school community, especially with coordinating teachers. Coordinating teachers' roles and responsibilities should be well informed;

- university supervisors should be selected among methodology instructors to enable them to supervise pre-service teachers effectively.

\section{Purpose of the study}

The study aimed to find out the extent to which pre-service teachers benefit from teaching practice or experience problems during the practicum. These issues were selected as the focus of the study because the reflection of pre-service teachers on their first real life teaching experiences would offer valuable insights and shed light on efforts to improve teacher education and teaching practice applications.

In order to examine the above issues, the study sought answers to the following questions: (1) What have pre-service teachers learnt from teaching practice? and (2) What problems did pre-service teachers have during their practicum?

\section{Method}

\section{Subjects}

In order to examine the concerns about and the benefits from teaching practice, the present study investigated a practicum program in English language teaching in Cyprus, a typical environment where English is learned as a foreign rather than second language. The number of pre-service teachers involved in the study was 122, conducting teaching practice in 12 different schools as part of their $4^{\text {th }}$ year of the teacher education program. The schools were organized as follows: 2 primary, 5 lower secondary and 5 upper secondary schools. The classes included both the elementary and pre-intermediate levels of English as a foreign language. Considering the fact that the pre-service teachers provided a self-evaluation report for each of their teaching practice sessions, they provided a rich data to be examined. The study also involved 4 university practicum supervisors and 42 coordinating teachers.

\section{Structure of the teaching practice course}

For a minimum of 10 weeks the pre-service teachers spent six hours a week at school, observing and teaching in a classroom environment. They were expected to teach 
a minimum of 6 hours during their teaching practice time. The pre-service teachers were expected to keep the following in the portfolio in an organized manner:

- an introduction section outlining the tasks carried out at school and the context of the teaching practice experience, including a description of the student population, name of the coordinating teacher(s), time frame for teaching, and units or lessons that were taught;

- $\quad$ signed record of activities and teaching hours;

- complete observation forms used by coordinating teacher(s) to observe pre-service teachers;

- lesson plans and their evaluations using the self-evaluation form in chronological order of teaching;

- weekly semi-structured journal entries to reflect on pre-service teachers' teaching experience;

- a videotape showing the pre-service teacher teaching a lesson from the selected unit;

- a written report of feedback, evaluations, and recommendations received from the coordinating teacher and the university supervisor;

- $\quad$ worksheets or other materials used during teaching;

- $\quad$ any other items (written or other visual materials);

- a two-page summary of teaching practice experience;

- $\quad$ any other rules and regulation that deemed to be significant.

The portfolio provided pre-service teachers with a great chance to reflect on their experiences through reflective journals, self-evaluation forms and summary reports. Reflective journals and their benefits are highlighted in the literature review (Loughran, 1996). As Loughran (2002, p. 35) puts it, pre-service teachers will not only have a chance to record their experiences but will have a chance to turn their experience into learning through reflection: "Experience alone does not lead to learning; reflection on experience is essential".

The university supervisors provided consultation to pre-service teachers before their teaching. Weekly consultation sessions were also organized by the university supervisor to provide feedback and reflect on pre-service teachers' practicum. Following the observational sessions, the University supervisors provided feedback reports to pre-service teachers for each of the observational sessions. The coordinating teachers at schools were selected by the school administration to work in close consultation with pre-service teachers. The coordinating teachers provided evaluation and assessment reports for two teaching sessions for each pre-service teacher.

\section{Sources of data}

The data regarding the pre-service teachers' reflection on their concerns, opinions and teaching experiences were obtained from their portfolios submitted at the end of the practicum period. Their self-evaluation forms (see Appendix), weekly journal 
entries, summary sections of their teaching practice experience, the reports from both the coordinating teachers and the university supervisor formed the basis for data gathering.

\section{Data analysis}

First the statements from the pre-service teachers were analysed and "key words and key sentences" were selected (Richards \& Farrell 2012, p. 7). Then each statement was related to a category. Each category was organized under different labels. For instance, the first category "benefits from teaching practice" was organized under such labels as "materials preparation", "real life experiences", "classroom management", etc. Following this procedure, frequency ratings were obtained for each label. The frequency ratings indicated the number of statements made for each label. Other supplementary information obtained from both the coordinating teachers and the university supervisor was also referred to during the formulation of categories and the interpretation of pre-service teachers' statements. Three categories were formed as the basis for data analysis which were a) what pre-service teachers learnt from teaching practice experience, $b$ ) the lessons they took, $c$ ) the problems they experienced.

\section{Results}

\section{Perceived Benefits}

The pre-service teachers' perceived benefits from teaching practice are indicated in Table 1 below.

Table 1. Benefits Derived from Teaching Practice

\begin{tabular}{|r|l|c|}
\hline & \multicolumn{1}{|c|}{ Benefits } & Frequency \\
\hline 1. & Materials preparation & 33 \\
\hline 2. & Real life teaching experiences & 21 \\
\hline 3. & Classroom management & 20 \\
\hline 4. & Creating real life teaching situations & 9 \\
\hline 5. & Noticing my shortcomings & 9 \\
\hline 6. & Learning how to implement effective methods & 7 \\
\hline 7. & Designing interactive activities & 7 \\
\hline 8. & Encouraging creativity & 7 \\
\hline 9. & Choosing teaching as a career & 6 \\
\hline 10. & Improving communication & 6 \\
\hline
\end{tabular}

Source: own elaboration. 
As the above table shows, materials preparation, which was indicated by 33 pre-service teachers, was the greatest benefit received from teaching practice. The second biggest benefit (n: 21) was related to having a chance to experience real life teaching opportunities. One pre-service teacher reflected a common view on the importance of real-life experiences in the following: "One hour of teaching equals 10 hours of university lecture in the teacher education program". Some of the pre-service teachers who had not considered teaching prior to their teaching practice changed their minds.

Classroom management also received a great number of responses (n:20) as a large benefit. The first three items in Table 1 represented almost half of the statements indicated as benefits.

The results regarding the learning outcomes for teaching practice in general partly resemble those obtained from previous research. Both this and Peter's (2008) research produced similar results in that classroom management and teaching were indicated as significant gains. However, the items "communication" and "catering for diverse needs" did not receive due attention in the present study.

\section{Pre-service Teachers' Concerns}

As shown in Table 2 below, the most frequently indicated problem was teaching related (n: 33), and included sub-labels such as "adjusting the level of activities", "giving clear instructions", "too much use of white board", "voice control", etc. Teacher-related problems need careful consideration and analysis as it was revealed that the two most frequently indicated items were "adjusting the level of activities" and "giving clear instructions". The high frequency rate on "adjusting the level" can be attributed to the lack of time to get to know the students to identify their level appropriately. Clarity of instruction is a methodological issue and the justification from the course conveyer was that they did not have enough time to focus on the practical applications on giving clear instructions during the course.

Table 2. Pre-service Teachers' Problems

\begin{tabular}{|c|l|c|}
\hline & \multicolumn{1}{|c|}{ Problems } & Frequency \\
\hline 1. & Teaching related & 33 \\
\hline 2. & Classroom management & 16 \\
\hline 3. & Coordinating teachers & 15 \\
\hline 4. & Time management & 10 \\
\hline 5. & Adjusting the level of activities & 5 \\
\hline 6. & Giving clear instructions & 3 \\
\hline 7. & Inappropriate materials & 2 \\
\hline
\end{tabular}

Source: own elaboration. 
Teaching related problems were followed by classroom management (n: 16) and time management (n: 10). These outcomes match the results of Valdez et al.'s (2000) and Swennen et. al.'s (2004) studies which indicated teaching related issues as the biggest problem. Likewise, Liaw's (2012) and Valdez et al.'s (2000) studies also reported classroom management to be a significant concern.

It was natural for pre-service teachers to have this kind of problems as they experienced real teaching environments for the first time. However, some other explanations could be offered for this outcome such as the lack of time spent on practical applications on classroom management courses in the teacher education program. This result confirms other studies which refer to inadequate practical training in classroom management (Hogan, Rabinowitz \& Craven, 2003; Can \& Basturk, 2018; Ozdas, 2018; Ramirez, 2019).

Following management problems, coordinating teachers were mentioned 15 times as problems they experienced. Some coordinating teachers were perceived as supportive but other pre-service teachers expressed their regret about the support they received from them. One pre-service teacher's statement explains the problem: "I was not allowed to follow the teaching methods taught at University. Some preservice teachers pointed out the coordinating teachers' lack of knowledge on new teaching methods. Such an outcome was also revealed by other research."

As stated by the university supervisors, the assignment of coordinating teachers to pre-service teachers was done on the basis of availability of teachers rather than their knowledge and skills. Therefore, selection of the coordinating teachers was not done effectively. The inappropriate selection of coordinating teachers was also emphasized in previous research (Ingvarson 2005, as cited in Uusimaki, 2009; Zeichner, 1996; 2010).

Despite the common belief, experience played a negative role among coordinating teachers in that usually young teachers were enthusiastic about and familiar with the sort of materials pre-service teachers designed. The longer-service coordinating teachers were not happy as they expressed indirectly that the pre-service teachers had set a "bad" example because the students asked the regular teachers to provide colourful materials similar to those designed by the pre-service teachers.

Most pre-service teachers $(\mathrm{n}=108)$ perceived the support they received from their university supervisors as more helpful. Such an outcome is parallel with Farrell's (2008), and Pennington and Urmston's (1998) results.

\section{Conclusion}

Pre-service teachers indicated that they learnt a lot from teaching practice opportunities. As an interesting outcome of their experience in teaching practice, some pre-service teachers decided to take up teaching as a career which they had not considered before. 
The results obtained regarding the benefits from teaching practice were both similar to (i.e. classroom management and teaching) and different from (i.e. communication and catering for diverse needs) previous research. "Catering for diverse needs", which was a major issue in other studies, was not emphasized in this study maybe because the classes were intact and did not involve mixed ability groups of students.

Pre-service teachers experienced some problems during their teaching practice as well. Their problems concern teaching, classroom management, and lack of support from coordinating teachers. One of the most striking outcomes of the study was that some coordinating teachers were perceived as unsupportive, controlling, traditional, and teacher-centred. It was interesting to observe that longer-service coordinating teachers surprisingly followed conventional approaches to teaching, and discouraged pre-service teachers to follow unconventional methods of teaching. Pre-service teachers complained that most of the coordinating teachers just followed the textbooks, and did not challenge their students with interesting, relevant and innovative tasks and activities. They also failed to keep abreast of new developments in the design of task-based materials. Another outcome about coordinating teachers was that their selection was not done effectively.

The study also confirmed the significance of effective integration of theory into practice. Students should have opportunities to put theory into practice in every area of their learning in campus-based courses. As the methodology and materials design courses were linked to real life situations with practice opportunities, student teachers did not indicate teaching methods and techniques as a big problem during their teaching practice experience. The methodological problems at the micro level regarding classroom activities and materials were indicated to a small extent.

Such a benefit was not obtained from the area of classroom management, which posed a serious problem for pre-service teachers probably because the classroom management course they took in their teacher training program was not handled in a practical manner.

Another important finding of this study is that it was rather the practicum opportunity itself than the support coming from coordinating teachers that played a role in the pre-service teachers' development and progress. They perceived their university supervisors to be providing more insights into their teaching experience

\section{Further research}

The study shed lights on possible directions for the improvement of practicum programs which are an important pre-requisite for effective teacher education. The results obtained from the study need to be further investigated to examine the connection between the extent of the practical applications in the campus-based courses and the problems perceived by pre-service teachers during teaching practice. 
The preliminary results putting the teaching practice opportunity itself in the foreground rather than the support obtained from coordinating teachers also deserves further investigation.

\section{Appendix. Self-evaluation guideline}

- Was the lesson successful? How do you know you have/haven't been successful?

- What did you like/dislike about the lesson?

- Did you do what was in your lesson plan?

- In what ways was your lesson different form your lesson plan?

- Did the students respond in (un)expected ways?

- Did you experience any difficulties or problems?

- Do you think you achieved the objectives outlined in your plan?

- If you were to have the opportunity to teach the lesson again, what would you do the same? What would you do differently?

- Did the students learn what were the intended to learn? What was this? Was it difficult for them?

- Which activities did they enjoy the most? Why?

- Were most of the students involved in the lesson? Why? Why not?

- What did you learn from the experience of teaching this lesson?

- Other comments?

\section{References}

Brandt, C. (2006). Allowing for practice: a critical issue in TEOL teacher preparation. ELT Journal, 6o(4). doi:10.1093/elt/cclo26.

Briggs, L.D., \& Richardson, W.D. (1992). Causes and sources of student concerns for student teaching problems. College Student Journal, 268-272.

Bullough, R. V, Draper, M. J., Smith, L., \& Burrell, J. (2004). Moving beyond collusion: Clinical faculty and university/public school partnership. Teaching and Teacher Education, 20, 505-521.

Can, D. T. \& Basturk, M. (2018). Qualitative research: the pre-service EFL teachers' opinions on teaching practicum. Trakya Üniversitesi Sosyal Bilimler Dergisi, 20(1), 187-212.

Cavanagh, M., Barr, J., Moloney, R., Lane, R., Hay, I., \& Chu, H. (2019). Pre-service teachers' impact on student learning: Planning, teaching, and assessing during professional practice. Australian Journal of Teacher Education, 44(2). http:// dx.doi.org/10.14221/ajte.2018v44n2.5.

Chan, K. W., \& Leung, M. T. (1998). Hong Kong pre-service teachers' focus of concerns and confidence to teach - a perspective of teacher development. Paper presented 
at the AnnualConference of Australian Association for Research in Education, Adelaide, Australia.

Clarke, A., \& Collins, S. (2007). Complexity science and student teacher supervision. Teaching and Teacher Education, 23, 160-72.

Clement, M. (1999). Reducing the stress of student teaching, Contemporary Education, 70(4), 20-27.

Darling-Hammond, L. (2006). Constructing 21st-century teacher education. Journal of Teacher Education, 57(3), 300-314. doi: 10.1177/0022487105285962

Eby, L. T., McManus, S. E., Simon, S. A., \& Russell, J. E. A. (2000). The protégés perspective regarding negative mentoring experiences: The development of a taxonomy. Journal of Vocational Behavior, 57, 1-21.

Elligate, J. E. (2007). Developing better practice for beginning primary teachers: The significance of practicum (Unpublished doctoral dissertation). Australian Catholic University.

Farrell, T. S. C. (2008). 'Here's the book, go teach the class': ELT practicum support. RELC, 39(2), 226-241.

Gezegin-Bal, B., Balıkçı, G. \& Gümüşok, F. (2019). Professional development of pre-service teachers in an English language program. International Online Journal of Education and Teaching (IOJET), 6(3), 624-642.

Goh, P. S., \& Matthews, B. (2011). Listening to the concerns of student teachers in Malaysia during teaching practice. Australian Journal of Teacher Education, 36(3), 92-103.

Guyton, E., \& D.J. McIntyre (1990). Student teaching and school experiences. In W. R. Houston (Ed.). Handbook of research in teacher education (pp. 514-534). New York: MacMillan.

Hansford, B. C., Ehrich, L. C., \& Tennent, L. (2004). Outcomes and perennial issues in pre-service teacher education mentoring programs. International Journal of Practical Experiences, 8(2), 6-17.

Harwell, D. R., \& Moore, J. L. (2010). Issues of concern related to practicum experiences in undergraduate education programs. Academic Leadership, 8(2).

Hogan, T., Rabinowitz, M., \& Craven, J. A. (2003). Representation on teaching: inferences from research of expert and novice teachers. Educational Psychologist, 38(4), 235-247.

Kyriacou, C., \& Stephens, P. (1999). Student teachers' concerns on teaching practice. Evaluation \& Research in Education, 13(1), 18-31.

Liaw, E. (2012). Learning to teach: A descriptive study of student language teachers in Taiwan. English Language Teaching, 5(12), 152-162.

Liston, D., Whitcomb, J., \& Borko, H. (2006). Too little or too much: Teacher preparation and the first years of teaching. Journal of Teacher Education, 57(4), 351-358.

Masadeh, T. S. Y. (2017). Opportunities and barriers of practicum from the perspectives of English language student teachers. Universal Journal of Educational Research, 5(6), 1059-1071. 
McDonald, C. (1993). Coping with stress during the teaching practicum: the student-teachers' perspective, The Alberta Journal of Educational Research, 39(4), 407-418.

Mitchell, M. \& Schwager, S. (1993). Improving the student teaching experience: looking to the research for guidance, Physical Educator, 50(1), 31-42.

Naylor, D. A., Campbell-Evans, G., \& Maloney, C. (2015). Learning to Teach: What Do Pre-service Teachers Report. Australian Journal of Teacher Education, 40(11). http://dx.doi.org/10.14221/ajte.2015V4on11.7.

Ozdas, F. (2018). Evaluation of pre-service teachers' perceptions for teaching practice course. Educational Policy Analysis and Strategic Research, 13(2), 87-103. doi: 10.29329/epasr.2018.143.5.

Pennington, M., \& Urmston, A. (1998). The teaching orientation of graduating students on a BATESL course in Hong Kong: A comparison with first-year students. Hong Kong Journal of Applied Linguistics 3, 17-45.

Peters, J. (2008, December). Sustaining student teachers' commitment: the role of first practicum experiences. Paper presented at AARE Conference, Brisbane.

Ramirez, I. A. (2019). Teaching senior high school: Through the eyes of student intern. International Journal of Multidisciplinary Approach and Studies, 6(3).

Ramsey, G. (2000). Review of teacher education. Sydney: NSW Department of Education.

Richards, J. C., \& Farrell, T. S. C. (2011). Practice teaching: A reflective approach. Cambridge, UK:

Rorrison, D. (2011). Border crossing in practicum research: Reframing how we talk about practicum. In M. Mattsson, T. V. Eilertsen \& D. Rorrison (Eds.), A practicum turn in teacher education (pp 19-44). Rotterdam: Sense Publishers.

Stuart, C., \& Thurlow, D. (200o). Making it their own: pre-service teachers' experiences, beliefs, and classroom practices. Journal of Teacher Education, 51(2), $113-121$.

Swennen, A., Jörg, T. \& Korthagen, F. (2004). Studying student teachers' concerns, combining image-based and more traditional research techniques. European Journal of Teacher Education, 27(3), 265-283.

Tas, M. A. \& Karabay, A. (2016). Developing teaching skills through the school practicum in Turkey: A metasynthesis study. Journal of Education and Training Studies, 4(11).

Uusimaki, L. (2009). Pre-service teacher education and the development of middle school teacher identity: An exploratory study (Unpublished doctoral dissertation). Queensland University of Technology, Australia.

Valdez, A., Young, B., \& Hicks, S. J. (2000). Pre-service teachers' stories: content and context. Teacher Education Quarterly, 27(1), 39-58.

Veenman, S. (1984). Perceived problems of beginning teachers. Review of Educational Research, 54(2), 143-178. 
Zeicher, K. (2010). Rethinking the connections between campus courses and field experiences in college- and university-based teacher education. Journal of Teacher Education, 61(1-2), 89-99.

Zeichner, K. (1990). Changing directions in the practicum: Looking ahead to the 1990s. Journal of Education for Teaching, 16(2), 105-132.

Zeichner, K. (1996). Designing educative practicum experiences for prospective teachers. In K. Zeichner, S. Melnick \& M. L. Gomez (Eds.). Currents of reform in pre-service teacher education (pp. 215-234). New York: Teachers College Press.

Zeichner, K. (2006). Reflections of a university-based teacher educator on the future of college- and university-based teacher education. Journal of Teacher Education, 57, 326-340.

Zeichner, K. M., \& Gore, J. (1990). Teacher socialization. In W. R. Houston, M. Haberman, J. P. Sikula, \& Association of Teacher Educators (Eds.), Handbook of research on teacher education (pp. 329-348). New York: Macmillan.

\section{PROBLEMY I KORZYŚCI PRAKTYK NAUCZYCIELSKICH W OPINIACH PRAKTYKANTÓW}

Streszczenie: Głównym celem badania były korzyści, jakie odnoszą praktykanci (n: 122) z praktyk nauczycielskich. Do analizy dokumentów wykorzystano dane z portfolio praktykantów, składających się z formularzy samooceny, cotygodniowych wpisów do dziennika praktyk i raporty podsumowujące ich doświadczenia w nauczaniu. Wyniki wskazują, że a) praktyka nauczycielska jest punktem zwrotnym dla przyszłych nauczycieli, b) większą korzyść przyniosła sama strona praktyczna, a nie wsparcie nauczycieli koordynujących, c) wybór nauczycieli koordynujących nie został przeprowadzony skutecznie, d) nauczyciele koordynujący stosowali konwencjonalne metody, e) im bardziej praktyczne są zajęcia uniwersyteckie, tym mniej problemów napotykają praktykanci.

Słowa kluczowe: praktykanci; praktyki; korzyści z praktyk; trudności na praktykach; kształcenie nauczycieli.

Bayram Pekoz received his Master's and doctoral degrees in TESOL from the University of New South Wales, Australia. He has worked as a teacher trainer, head of ELT department and director of school of foreign languages at several universities. Among his research and teaching interests are $\mathrm{L} 2$ teacher education, task-based learning, materials development and language testing. He currently works as assistant professor in ELT department at Hasan Kalyoncu University, Turkey. Postal address: Hasan Kalyoncu University, Faculty of Education, Department of English Language Teaching, Gaziantep, Turkey. E-mail: bayram.pekoz@hku.edu.tr 